\title{
DETECTION OF BOVINE LEUKOCYTE ADHESION DEFICIENCY, DEFICIENCY OF URIDINE MONOPHOSPHATE SYNTHASE, AND COMPLEX VERTEBRAL MALFORMATION IN HOLSTEIN CATTLE
}

\author{
Kristina Morkūnienè, Renata Bižienè, Nijolè Pečiulaitienè, Rasa Ugenskienè \\ Lithuanian University of Health Sciences, Institute of Biology Systems and Genetics, Tilzes st. 18, Kaunas, Lithuania \\ ${ }^{*}$ Corresponding author, E-mail: kristina.morkuniene@|smuni.lt
}

\begin{abstract}
This research aimed to evaluate the prevalence of the most common lethal diseases in the Lithuanian Holstein cattle population. Two hundred non-related (based on the documentation of origin) cattle (cows and heifers) were included in the study. DNA extraction from blood leukocytes was performed using the chloroform salt method. The cattle were tested for three inherited bovine disorders: bovine leukocyte adhesion deficiency (BLAD), deficiency of uridine monophosphate synthase (DUMPS), complex vertebral malformation (CVM). The PCR-RFLP test method was used to determine the polymorphism of the CD18gene, which is responsible for $B L A D$ inherited disorder development. A recessive allele with point mutation $A \rightarrow G(383)$, causing $B L A D$, was found in the Lithuanian cattle population with 0.0025 frequency. CVM disease is determined by the missense mutation, which has been found in the SLC35A3gene. The study was performed using a sequencing method. A recessive allele with point mutation $G \rightarrow T$ (538), causing CVM, was found in the Lithuanian cattle population with 0.005 frequency. The PCR-RFLP test method was used to determine the polymorphism of the UMPS gene, responsible for DUMPS inherited disorder development. A recessive allele with point mutation C $\rightarrow T$ (1213), causing DUMPS, was not found in the Lithuanian Holstein cattle population. Because intensive selection programmes were performed over the previous decade, the number of heritable lethal diseases carriers has significantly decreased.
\end{abstract}

Key words: cattle; bovine leukocyte adhesion deficiency; deficiency of uridine monophosphate synthase; complex vertebral malformation; BLAD;DUMPS; CVM

\section{Introduction}

Modern breeding of dairy cattle increasingly involves programmes based on the international trade of semen from elite bulls with high genetic merit. With the widespread use of advanced reproductive technologies, including artificial insemination and multiple ovulation embryo transfer, individual bulls are able to sire thousands of heifers in many countries (1). In that way, more than ten genetic diseases have spread, some of them resulting in fatal outcomes and causing

Received: 14 December 2018

Accepted for publication: 21 May 2019 significant economic losses. These include bovine leukocyte adhesion deficiency (BLAD), deficiency of uridine monophosphate synthase (DUMPS), and complex vertebral malformation (CVM) $(2,3$, $4,5,6,7)$.

With intensive livestock development, a single breed begins to dominate in separate animal species (e.g., the Holstein breed) among dairy cattle, and a small number of reproducers are used for fertilisation in such breeds. Consequently, genetic biodiversity is significantly reduced, many genes became homozygous, and abundant genetic diseases can occur. Animals carrying various genetic defects must be eliminated from the population so that the frequency of the undesired 
gene does not increase to the critical limit, at which point it becomes homozygous and manifests phenotypically. If the animal is only the carrier of unwanted genes, this gene is not phenotypically detectable, and the study can only be performed using genetic testing methods, so it is essential to analyse breeding livestock in order to prevent the spread of the undesired gene.

Known inherited disorders in cattle are mostly caused by autosomal recessive inherited genes. Heterozygous individuals can be identified using different methods, such as examination of progeny, clinical examination or necropsy, analysis of enzyme activity in blood, and genotyping of animals by genomic analysis. Recent developments within molecular genetics have made possible the efficient and rapid identification of heterozygous animals via genomic analysis. Knowing the molecular basis of a defect, the direct detection of carriers is possible at the genetic level, thus preventing the breeding of the ineligible animal (8). At present, there are identification records for several inherited bovine disorders, including. bovine leukocyte adhesion deficiency (BLAD), deficiency of uridine monophosphate synthase (DUMPS), complex vertebral malformation (CVM), bovine citrullinaemia (BC), and factor XI deficiency (FXID).

The congenital calf immune deficiency BLAD is a lethal autosomal recessive hereditary disease manifested in Holstein breed calves. The disease was diagnosed for the first time by the American scientist Marco E. Kehrli in 1990 (9). Dale E. Shuster and other researchers have identified the CD18 gene nucleotide sequence of the healthy bovine and mutated $C D 18$ gene (10). The mutation of the same gene was found in humans (11) and dogs (12). Heterozygous individuals are clinically healthy, but heterozygous bulls and cows have a $25 \%$ probability of producing homozygous calves with this disease. The BLAD disease gene is present in the BTA1 bovine chromosome. Due to the mutation, the gene responsible for the synthesis of glycoprotein-beta-integrin has been altered. This results in the synthesis of inadequate beta-integrin as in the position 128 of the protein molecule, the aspartic amine acid is replaced with glycine. Calves with two mutated alleles, which in homozygote status causes bovine BLAD, often have infections in the gastrointestinal tract and respiratory tract. Calves with BLAD are born with small body weight, grow and eat poorly, and their coat is not shiny. Calves are highly prone to infections, and are often suffering from enteritis, pneumonia, diarrhoea, ulcers, laryngitis, granulation stomatitis, gingivitis, peripheral lymphadenopathy, anaemia, and, if not treated, they usually die at 2-3 months of age. From the year 2000 to 2018 in Lithuania, the frequency of mutated allele, which in homozygote status causes bovine BLAD, decreased because of the intensive selection against this allele.

The deficiency of uridine monophosphate synthase (DUMPS) is an autosomal recessive lethal Holstein breed bovine disease characterised by early embryonic mortality $(13,14,15)$. UMPS (uridine monophosphate synthase) is an enzyme that is essential in the synthesis of pyrimidine nucleotides. It is indispensable for the normal growth and development of ruminants and other species of animals. The inactivation of this enzyme is caused by a point mutation in the UMPS gene $(\mathrm{C} \rightarrow \mathrm{T}), 405$ codon of the 5 exon. This Holstein cattle disorder is characterised by a decrease of UMPS enzyme activity in the blood (16). DUMPS causes foetal death in the early stages of pregnancy and many reproductive problems in dairy herds. The gene responsible for lack of the enzyme uridine monophosphate is found on chromosome 1 of bovine animals. In mammalian cells, the final step of the pyrimidine nucleotide synthesis comprises the conversion of orotate to urinary monophosphate and is catalysed by the UMP synthase enzyme. UMP synthase is essential for the synthesis of novel pyrimidine nucleotides, which are components of DNA and RNA. Since pyrimidines are essential for nucleic acid synthesis during embryonic development, embryos that are homozygous for a recessive allele die up to the $40^{\text {th }}$ days of gestation. Embryos are often absorbed during the first two months of pregnancy, and these cows return to oestrus. This leads to increased intervals between calving (13, $14,15)$. Heterozygous animals are phenotypically normal, but only half of normal UMPS enzyme activity occurs, which causes an increase in the amount of orotic acid in their milk and urine (16). To date, no live animals have been found that are homozygous for the mutated allele (15).

Complex Vertebral Malformation (CVM) is an autosomal recessive Holstein cattle disease inherited as severe spinal degeneration. The syndrome was first identified in the year 2000 in the Danish Holstein population $(3,17,18)$. The 
disease was also found in the Wagyu breed. The first ancestor of the cattle that had this mutation was a bull named Carlin-M Ivanhoe Bell (19). Severe Vertebral Malformation (CVM) is determined with both aborted foetuses and prematurely born dead calves. Affected calves have anomalies in the spinal column, such as not fully developed, broken, or unusually formed spinal vertebrae and ribs, scoliosis, and spinal synostosis. Low body weight and heart abnormalities are also observed (20). Such calves have shorter spine and chest areas, symmetrical contractions of meta-tarso-phalange joints on both sides and symmetrical arthrogryposis (17). Severe Vertebral Malformation (CVM) is caused by a mutation in the BTA3 chromosome, which replaces the amino acid sequence; instead of valine, phenylalanine is formed, in the 180 position of the protein uridine 5'-diphosphate- $\mathrm{N}$-acetylglucosamine (21). This gene is responsible for the transportation of UDP$\mathrm{N}$-acetylglucosamine into the Golgi apparatus membrane; $80 \%$ of embryos that have inherited a gene mutation of CVM disease from both parents will be lost during the first three months of gestation. An aborted sick calve will have a shortened neck due to spinal cord injury, as well as altered ribs, limbs and interdigital joints. In addition, symptoms such as partial pulmonary hypoplasia, excessive liver segmentation, double gall bladder, as well as rectum and uterine atresia may occur (22). Heterozygous animals are carriers of the mutated gene.

In animal breeding, genetic disorders are one of the most imperative issues for breeders. Due to the negative influence of such disorders on animals, through abnormal anatomy or reduced production, breeders and breeding associations need to control the impact on the population.

\section{Material and methods}

The animals for this study were selected from dairy herds, in which breeding record and cattle productivity control were carried out. The farms were located in four different regions of Lithuania. In each dairy herd, 50 non-related (based on the documentation of origin) cattle (cows and heifers) were selected. In total, 200 dairy cattle were tested. They were healthy, and kept and fed according to hygiene norms; the conditions for keeping and feeding were in line with veterinary requirements.
Blood for genetic testing was collected in aseptic conditions from the cephalic vein in vacuum tubes (Vacutainer) with $\mathrm{K}_{2}$ EDTA (ethylenediamine tetraacetate) anticoagulant. The blood was stored at $+4{ }^{\circ} \mathrm{C}$ until the test. DNA extraction from blood leukocytes was performed using the chloroform salt method, according to Miller et al. (23). Genomic DNA content and purity were determined using the spectrophotometric method (DNA/RNA Reader, Pharmacia).

\section{BLAD genetic disease PCR-RFLP test method (10)}

For the identification of mutation c.383A $>\mathrm{G}$ (g. 145114963A $>\mathrm{G}, \mathrm{rs} 445709131$ ) in the $C D 18$ gene, causing a change of adenine to guanine in the 383 position of the gene and manifesting as BLAD in cattle, the PCR-RFLP test method was used. We targeted a $357 \mathrm{bp}$ long fragment of the fifth exon of the gene of the BLAD disease locus (Table 1).

$10 \mu 1$ of DNA and $15 \mu 1$ of PCR mixture were poured into the tube. The PCR reaction was performed using a thermocycler (G-storm, United Kingdom). Reagents used: PCR Mix - 2.95 $\mu 1 \mathrm{ddH}_{2} \mathrm{O}$; $2.5 \mu 1$ 10xPCR buffer; $2.5 \mu 1$ of dNTP $(2 \mathrm{mM}) ; 1.5 \mu 1$ of $\mathrm{MgCl}_{2} ;(50 \mathrm{mM}) ; 2.5 \mu \mathrm{l}$ of the forward primer $(20$ pmol); $2.5 \mu 1$ of the reverse primer (20 pmol); $0.25 \mathrm{ml}$ BSA; $0.3 \mu 1$ Taq polymerase (Thermo Scientific, Lithuania); in two places in the same column $10 \mu 1$ of the PCR product was digested with $10 \mu 1$ of the restriction mix $\left(7.5 \mu 1 \mathrm{ddH}_{2} \mathrm{O}, 2 \mu \mathrm{l} 10 \times\right.$ buf., $0.5 \mu 1$ Taq ). Samples were left in a thermostate for 1 hour at $65^{\circ} \mathrm{C}$. The digested PCR products were fractionated using electrophoresis in $2.5 \%$ agarose gel, $100 \mathrm{~V} 40 \mathrm{~min}$. The gel was stained with ethidium bromide for 15-20 minutes and analysed in UV light (wavelength $300 \mathrm{~nm}$ ) with MiniBisPro Video Documentation (Herolab) (Table2).

\section{DUMPS genetic disease PCR-RFLP test method}

Testing method for nonsense (stop-gain) mutation c. $1213 \mathrm{C}>\mathrm{T}$ in UMPS gene (g.69756880C $>\mathrm{T}$ ) causing a change of cytosine to thymine in the 405 codon of the gene of the fifth exon and manifesting as DUMPS in cattle (Table 3).

$10 \mu 1$ of DNA and $15 \mu 1$ of PCR mixture were poured into the tube. PCR reaction was performed 
Table 1: Primers, PCR profile, PCR product size and restriction enzymes used for identification of genetic disease - BLAD

\begin{tabular}{|c|c|c|c|c|c|c|}
\hline $\begin{array}{l}\text { Genetic } \\
\text { defect }\end{array}$ & Primers & \multicolumn{3}{|c|}{ PCR profile } & $\begin{array}{l}\text { PCR product } \\
\text { size }\end{array}$ & $\begin{array}{l}\text { Restriction } \\
\text { enzyme }\end{array}$ \\
\hline \multirow[t]{5}{*}{ BLAD } & \multirow{5}{*}{$\begin{array}{l}\text { F: 5' GAATAGGCATCCTGCATCATATCCACCA 3‘ } \\
\text { R: 5‘ CTTGGGGTTTCAGGGGAAGATGGAGTAG 3“ }\end{array}$} & $94^{\circ} \mathrm{C}$ & $3 \mathrm{~min}$ & & 357 bp & TaqI \\
\hline & & $94^{\circ} \mathrm{C}$ & $30 \mathrm{~s}$ & \multirow[t]{3}{*}{33 cycles } & & \\
\hline & & $65^{\circ} \mathrm{C}$ & $30 \mathrm{~s}$ & & & \\
\hline & & $72^{\circ} \mathrm{C}$ & $30 \mathrm{~s}$ & & & \\
\hline & & $72^{\circ} \mathrm{C}$ & $5 \mathrm{~min}$ & & & \\
\hline
\end{tabular}

Table 2: $C D 18$ gene c.383A>G DNA fragments sizes in bp after digestion with restriction endonuclease

\begin{tabular}{|c|c|c|c|}
\hline $\mathrm{Bp}$ & Homozygous for normal allele & Heterozygous & Homozygous for disease allele \\
\hline 357 & - & - & \\
\hline 201 & & - & - \\
\hline 156 & & - & - \\
\hline
\end{tabular}

Table 3: Primers, PCR profile, PCR product size and restriction enzyme used for identification of genetic disease DUMPS

\begin{tabular}{|c|c|c|c|c|c|c|}
\hline $\begin{array}{l}\text { Genetic } \\
\text { defect }\end{array}$ & Primers & \multicolumn{3}{|c|}{ PCR profile } & $\begin{array}{l}\text { PCR product } \\
\text { size }\end{array}$ & $\begin{array}{l}\text { Restriction } \\
\text { enzyme }\end{array}$ \\
\hline \multirow[t]{5}{*}{ DUMPS } & \multirow[t]{5}{*}{$\begin{array}{l}\text { F: 5‘ GCAAATGGCTGAAGAACATTCTG 3“ } \\
\text { R: } 5^{\prime} \text { GCTTCTAACTGAACTCCTCGAGT } 3^{\prime}\end{array}$} & $94^{\circ} \mathrm{C}$ & $5 \mathrm{~min}$ & & $108 \mathrm{bp}$ & \multirow[t]{5}{*}{ AvaI } \\
\hline & & $94^{\circ} \mathrm{C}$ & $60 \mathrm{~s}$ & \multirow[t]{3}{*}{40 cycles } & & \\
\hline & & $58^{\circ} \mathrm{C}$ & $60 \mathrm{~s}$ & & & \\
\hline & & $72^{\circ} \mathrm{C}$ & $90 \mathrm{~s}$ & & & \\
\hline & & $72^{\circ} \mathrm{C}$ & $5 \mathrm{~min}$ & & & \\
\hline
\end{tabular}

Table 4: UMPS gene c.1213 C>T DNA fragments sizes in bp of cattle DUMPS causing gene after digestion with restriction endonuclease

\begin{tabular}{|l|c|c|c|}
\hline $\mathrm{Bp}$ & Homozygous for normal allele & Heterozygous & Homozygous for disease allele \\
\hline 89 & - & - & \\
\hline 53 & & - & - \\
\hline 36 & & - & - \\
\hline 19 & - & - & - \\
\hline
\end{tabular}

Table 5: Prevalence of BLAD, DUMPS and CVM diseases in Lithuanian Holstein population

\begin{tabular}{|l|c|c|c|c|c|c|}
\hline \multirow{2}{*}{ Genetic disease } & \multirow{2}{*}{ Gene } & \multicolumn{2}{|c|}{ Genotype frequency } & \multicolumn{2}{c|}{ Allele frequency } \\
\cline { 3 - 7 } & & $\begin{array}{c}\text { Homozygous for } \\
\text { normal allele }\end{array}$ & Heterozygous & $\begin{array}{c}\text { Homozygous for } \\
\text { disease allele }\end{array}$ & Normal & Mutated \\
\hline BLAD & CD18 & 0.995 & 0.005 & 0 & 0.9975 & 0.0025 \\
\hline CVM & SLC35A3 & 0.99 & 0.01 & 0 & 0.995 & 0.005 \\
\hline DUMPS & UMPS & 1 & 0 & 0 & 1 \\
\hline
\end{tabular}


using a thermocycler (G-storm, United Kingdom). Reagents used: PCR Mix - 2.95ml ddH $\mathrm{d}_{2} \mathrm{O} ; 2.5 \mathrm{ml}$ 10xPCR buffer; $2.5 \mathrm{ml}$ of dNTP $(2 \mathrm{mM}) ; 1.5 \mathrm{ml}$ of $\mathrm{MgCl}_{2} ;(50 \mathrm{mM}) ; 2.5 \mathrm{ml}$ of the forward primer $(20$ pmol); $2.5 \mathrm{ml}$ reverse primer $(20 \mathrm{pmol}) ; 0.25 \mathrm{ml}$ BSA; $0.3 \mathrm{ml}$ Taq polymerase (Thermo Scientific, Lithuania). $10 \mu \mathrm{l}$ of the PCR product was digested with $10 \mu \mathrm{l}$ of the restriction $\operatorname{mix}\left(7.5 \mu 1 \mathrm{ddH}_{2} \mathrm{O}\right.$, $2 \mu 110 \times$ buf., $0.5 \mu 1$ Aval). Samples were left in a thermostat for 10 hours at $37^{\circ} \mathrm{C}$. The digested PCR products were fractionated using electrophoresis on $4 \%$ agarose gel, $100 \mathrm{~V} 40 \mathrm{~min}$. The gel was stained with ethidium bromide for 15-20 minutes and analysed in UV light (wavelength $300 \mathrm{~nm}$ ) using MiniBisPro Video Documentation (Herolab) (Table 4).

\section{CVM genetic disease test method}

Investigations of polymorphism analysis of the gene for CVM disease in cattle was performed at the Neogen Genomics Corporation Laboratory (USA). The study was performed using a sequencing method. CVM disease is determined by the missense mutation, present in the SLC35A3 gene. In the third cattle chromosome, a modified SLC35A3 gene with a single base conversion c.538G $>\mathrm{T}$ (g. $43412427 \mathrm{G}>\mathrm{T}$, rs438228855) was detected.

\section{Results}

We tested cows for lethal autosomal recessive disorders widely distributed in the Lithuanian Holstein cattle population: bovine leukocyte adhesion deficiency (BLAD), deficiency of uridine monophosphate synthesis (DUMPS) and vertebral malformation $(\mathrm{CVM})$. A recessive allele with point mutation c.383A $>\mathrm{G}$, causing BLAD, was found in the Lithuanian cattle population with 0.0025 frequency; $0.5 \%$ of individuals were heterozygous. The recessive allele with point mutation c.1213 $\mathrm{C}>\mathrm{T}$, causing DUMPS, was not found in the Lithuanian cattle population. A recessive allele with point mutation c.538G $>\mathrm{T}$, causing CVM disease, was found in the Lithuanian cattle population with 0.005 frequency; $1.0 \%$ of individuals were heterozygous (Table 5).

In the year 2000, the percentage of Lithuanian dairy cattle population who were heterozygote animals, BLAD disease gene carriers, was $5 \%$; this percentage was $4 \%$ in 2002 , and $2 \%$ in 2004 . In
2018, we found $0.5 \%$ mutated allele carriers and distributors of disease genes in the population (Figure 1).

\section{Discussion}

Genomic selection is carried out not only to improve the genetic potential of cattle productivity, reproduction, and milk quality but also by assessing the signs of bovine health. In the dairy cattle population, due to the international breeding of males with high genetic value, despite also being the carriers of recessive genetic disease alleles, genetic diversity has been significantly reduced. As a result, many genes have become homozygous, producing abundant genetic diseases among the dairy cattle population, which causes significant economic losses, as many of them are lethal. After a retrospective assessment of the prevalence of the lethal genetic diseases of BLAD, DUMPS, and CVM in the dairy cattle population, the following was established.

CVM and BLAD have become some of the most common hereditary genetic defects of the Holstein breed in recent decades. Researchers found that in the year 2000 the mutant allele for BLAD disease frequency was $24 \%$, and the rate of mutated alleles for CVM in the German Holstein population from 2001 to 2007 ranged from 9\% up to $16 \%(6)$.

The mutated allele causing BLAD, c.383A $>\mathrm{G}$, was found at a frequency of $0.0025 \%$ in the Lithuanian dairy cattle population; with $0.5 \%$ of cattle being heterozygous while no homozygous animals with BLAD were found. Since 1999, all sires and selected cows used for breeding in Lithuania have the genotype for this disease recorded in the pedigree information. In Lithuania in the year 2000, $6.7 \%$ of key areas of the altered gene leading to BLAD disease were found among selected cows. Of the 146 bulls tested, 4 carriers were found. In 2002, 3\% of selected cows were carriers, and in 2004, $2 \%$ of selected cows and 1 young bull were carriers. All breeding bulls and selected cows that are newly introduced among breeding animals are compulsorily tested for BLAD disorder. A similar mutated allele frequency as in our study was reported in Czech cattle: $0.82 \%$ (24), and in Chinese Holsteins $(0.69 \%$; 25). However, a much larger mutated allele frequency was reported for Indian Holstein Friesian cattle (2.99\%) (26), 
Iranian Holsteins (3.3\%) (27), American Holsteins (8.2\%), Polish Holsteins-Friesian (7.9\%) (28) and Turkish Holstein cows (4.0\%) (29).

The mutated allele causing the DUMPS genetic disorder in cattle (c.1213 C>T), manifested as early mortality of cattle embryos due to the shortage of uridine monophosphate synthase, was not found in the Lithuanian population. No carrier animals of the DUMPS genetic disorder were found in Turkey $(2,29,30)$. Similar results were obtained in the research done by other scientists in Poland (13), the Czech Republic (24), Germany, India, Iran and Romania. However, the mutant DUMPS disease allele with a 1-2\% frequency was found in the Holstein breed in the USA, 0.96\% in Argentine Holstein bulls, and $0.06 \%$ in Chinese Holsteins.

The mutated allele causing CVM cattle disease (c. $538 \mathrm{G}>\mathrm{T}$ ), manifested in malformations of the foetal spine, was found in the population of Lithuanian dairy animals at the frequency 0.005, while the number of heterozygous bovines was found to be $1 \%$, and no homozygous bovine affected by CVM was found. In Turkey, the frequency of Holstein bovine CVM mutated allele carriers was $3.4 \%$ and $3.86 \%$ in the Chinese dairy population. A high frequency of mutated allele was found in Denmark with $31.0 \%$ of all cattle affected (21), in Poland at $24.8 \%$ (31), in Japan at $32.5 \%$ (32), in Sweden at $23.0 \%$ (33), in Germany, at $13.2 \%$ (34), and in China 15\% (19). Since the year 2000, breeding programmes in most counties have been implemented to reduce the prevalence of CVM carriers. However, in some Holstein populations, the incidence of CVM disorder carriers remains high (Denmark, Poland, Japan). A study of Iranian Holstein cattle did not identify heterozygous bovine animals (18). This can be associated with the use of a small number of bulls carrying the mutated allele for breeding, during the formation of the breed, and further selection.

In the Lithuanian dairy cattle population, lethal bovine diseases caused by recessive genes in the population were reduced because of an intense selection programme, eliminating the BLAD disease gene carriers and avoiding the use of BLAD, DUMPS, and CVM heterozygous bulls for breeding. The number of mutated allele carriers dropped from $6 \%$ in 2000 to $0.5 \%$ in 2018.

The incidence of hereditary diseases causes not only direct economic losses to livestock breeders but also leads to reductions in the genetic diversity of animal populations as a result of extensive culling of disease carriers. The identification of carriers with the use of molecular diagnostic tests is an important step in reducing the frequency of detrimental alleles and consequently lowering the incidence of hereditary diseases in the herd. This is particularly important when considering bulls inserted into progeny testing programmes because they can potentially sire thousands of progeny before the incidence of affected progeny can be associated with a particular animal.

\section{Conclusions}

An investigation of cows for the prevalence of the lethal genetic disorders BLAD, DUMPS, and CVM in the Lithuanian dairy cattle population showed $0.5 \%$ BLAD disease gene carriers and $1.0 \%$ CVM disease gene carriers. No DUMPS disease gene carriers have been found. In the Lithuanian Holstein cattle population, the number of carriers of heritable lethal diseases caused by recessive genes decreased, because of an intensive selection programme, eliminating mutated gene carriers, and avoiding the use of heterozygous bulls for the diseases BLAD, DUMPS, and CVM.

\section{References}

1. Windsor P, Agerholm J. Inherited diseases of Australian Holstein-Friesian cattle. Aust Vet J 2009; 87: 193-9.

2. Akyüz B, Ertuğrul O. Detection of deficiency of uridine monophosphate synthase (DUMPS) in Holstein and native cattle in Turkey. Ankara Üniv Vet Fak Derg 2008; 55: 57-60.

3. Agerholm JS, Andersen O, Almskou MB, et al. Evaluation of the inheritance of the complex vertebral malformation syndrome by breeding study. Acta Vet Scand 2004; 45: e133-7. https://www. ncbi.nlm.nih.gov/pmc/articles/PMC1820988/

4. Ohba Y, Takasu M, Nishii N, Hosoda I, Kitoh K, Matsumoto I. Japanese black cattle with orotic aciduria detected by gas-chromatography/ mass-spectrometry. J Vet Med Sci 2007; 69: 313-6.

5. Rusc A, Hering D, Puckowska P, Barcewicz M, Kaminski S. Screening of Polish Holstein-Friesian bulls towards eradication of Complex Vertebral Malformation (CVM) carriers. Pol J Vet Sci 2013; 16: 579-81.

6. Schütz E, Scharfenstein M, Brenig B. Implication of complex vertebral malformation and 
bovine leukocyte adhesion deficiency DNA-based testing on disease frequency in the Holstein population. J Dairy Sci 2008; 91: 4854-9.

7. Wang C, Tong Q, Hu XZ, Yang LG, Xhong $X Q$. Identification of complex vertebral malformation carriers in Holstein cattle in south China. Genet Mol Res 2011; 10: 2443-8.

8. Agerholm JS. Inherited disorders in Danish cattle. APMIS 2007; 115(Suppl. 122): 1-76.

9. Kehrli M, Schmalstieg FC, Anderson DC, Whetstone CA. Molecular definition of the bovine granulocytopathy syndrome: identification of deficiency of the Mac-1105 (CD11b/CD18) glycoprotein. Am J Vet Res 1990; 51: 1826-36.

10. Shuster DE, Kehrli Jr. ME, Ackermann MR, Gilbert RO. Identification and prevalence of a genetic defect that causes leukocyte adhesion deficiency in Holstein cattle. Proc Natl Acad Sci U S A 1992; 89(19): 9225-9.

11. Rosenzweig SD, Holland SM. Defects of innate immunity. In: Leung DYM, Szefler SJ, Bonilla FA, et al., eds. Pediatric allergy: principles and practice. $3^{\text {rd }}$ ed. Edinburgh etc. : Elsevier, 2016: 101-11.

12. Foureman P, Whiteley M, Giger U. Canine leukocyte adhesion deficiency: presence of the Cys36Ser beta-2 integrin mutation in an affected US Irish Setter cross-breed dog and in US Irish Red and White Setters. J Vet Intern Med 2002; 16(5): 518-23.

13. Kaminski S, Grzybowski G, Prusak B, Rusc A. No incidence of DUMPS carriers in Polish dairy cattle. Appl Genet 2005; 46: 395-7.

14. Kuhn MT, Shanks RD. Association of deficiency of uridine monophosphate synthase with production and reproduction. J Dairy Sci 1994; 77: 589-7.

15. Shanks RD, Greiner MM. Relationship between genetic merit of Holstein bulls and deficiency of uridine-5'- monophosphate synthase. J Dairy Sci 1992; 75: 2023-9.

16. Healy MH, Shanks RD. Performance of females heterozygous for deficiency of uridine monophosphate synthase. J Dairy Sci 1987; 70: 945-51.

17. Agerholm JS, Bendixen C, Andersen OJ. Complex vertebral malformation in Holstein calves. J Vet Diagn Invest 2001; 13: 283-9.

18. Rezaee AR, Nassiry MR, Sadeghi B, Motlagh AS. Implication of complex vertebral malformation and defciency of uridine monophosphate synthase on molecular-based testing in the Ira- nian Holstein bulls population. Afr J Biotechnol 2009; 8: 6077-81.

19. Chu Q, Sun D, Yu Y, Zhang Y, Zhang Y. Identification of complex vertebral malformation carriers in Chinese Holstein. J Vet Diagn Invest 2008; 20: 228-30.

20. Duncan RB, Carrig CB, Agerholm JS, Bendixen C. Complex vertebral malformation in a Holstein calf: report of a case in the USA. J Vet Diagn Invest 2001; 13: 333-6.

21. Thomsen B, Horn P, Panitz F, Bendixen E, Petersen AH, Holm LE. A missense mutation in the bovine SLC35A3 gene, encoding a UDP-Nacetylglucosamine transporter, causes complex vertebral malformation. Genome Res 2006; 16: 97-105.

22. Buck BC, Ulrich R, Wöhlke A, Kuiper H, Baumgärtner W, Distl O. Vertebral and multiple organ malformations in a black and white German Holstein calf. Berl Munch Tierarztl Wochenschr 2010; 123: 251-5.

23. Miller SA, Dykes DD, Polesky HF. A simple salting out procedure for extracting DNA from human nucleated cells. Nucleic Acids Res 1988; 16: 1215.

24. Citek J, Rehout V, Hajkova J, Pavkova J. Monitoring of the genetic health of cattle in the Czech Republic. Vet Med 2006; 51: 333-9.

25. Sun DX, Fan XH, Xie Y, et al. Short communication: Distribution of recessive genetic defect carriers in Chinese Holstein. J Dairy Sci 2011; 94(11): 5695-8.

26. Patel RK, Krishna MS, Kalpesh JS, Jenabhai BC, Krothapalli RS, Sambasiva R. Lack of carriers of citrullinaemia and DUMPS in Indian Holstein cattle. J Appl Genet 2006; 47: 239-42.

27. Norouzy A, Nassiry MR, Eftekhari SF, Javadmanesh $A$. Identification of bovine leucocyte adhesion deficiency (BLAD) carriers in Holstein and Brown Swiss AI bulls in Iran. Genetika 2005; 41: 1697-701.

28. Czarnik U, Grzybowski G, Kamiñski S, Prusak B, Zabolewicz T. Effectiveness of a program aimed at the elimination of BLAD-carrier bulls from Polish Holstein-Friesian cattle. J Appl Genet 2007; 48: 375-7.

29. Meydan H, Yildiz MA, Agerholm JS. Screening for bovine leukocyte adhesion deficiency, deficiency of uridine monophosphate synthase, complex vertebral malformation, bovine citrullinaemia, and factor XI deficiency in Holstein cows reared in Turkey. Acta Vet Scand 2010; 52: e56 
(1-8). https://actavetscand.biomedcentral.com/ articles / 10.1186/1751-0147-52-56

30. Öner Y, Keskin A, Elmaci C. Identification of BLAD, DUMPS, citrullinaemia and factor XI deficiency in Holstein cattle in Turkey. Asian J Anim Vet Adv 2010; 5: 60-5.

31. Rusc A, Kaminski S. Prevalence of complex vertebral malformation carriers among Polish Holstein-Friesian bulls. J Appl Genet 2007; 48: 247-52.

32. Nagahata H, Oota H, Nitanai A, et al. Complex vertebral malformation in a stillborn Holstein calf in Japan. Vet Med Sci 2002; 64: 1107-12.

33. Berglund B, Persson A, Stalhammar H. Effects of complex vertebral malformation on fertility in Swedish Holstein cattle. Acta Vet Scand 2004; 45: e161-5.

https://www.ncbi.nlm.nih.gov/pmc/articles / PMC1820991/

34. Konersmann Y, Wemheuer W, Brenig B. Herkunft, verbreitung und bedeutung des CVM gendefekts in der Holstein Friesian population. Züchtungskunde 2003; 75: 9-15.

\title{
UGOTAVLJANJE POMANJKLJIVE ADHEZIJE GOVEJIH LEVKOCITOV, POMANJKANJA ENCIMA URIDIN MONOPOSFAT SINTETAZE TER KOMPLEKSA MALFORMACIJE VRETENC PRI HOLŠTAJNSKEM GOVEDU
}

\author{
K. Morkūnienè, R. Bižienè, N. Pečiulaitienè, R. Ugenskienè
}

Povzetek: Namen raziskave je bil oceniti razširjenost najpogostejših smrtnih bolezni v populaciji litvanskega holštajnskega goveda. V študijo je bilo vključenih dvesto nesorodnih (na podlagi dokumentacije o poreklu) krav in telic. Izolacijo DNK iz krvnih levkocitov smo izvedli z metodo izolacije s soljo in kloroformom. V vzorcih DNK krav in telic smo preverili prisotnost mutacij v treh genih, ki povzročajo naslednje bolezni: motnjo prilepljanja govejih levkocitov (BLAD), pomanjkanje encima uridin monofosfat sintaze (DUMPS) ter kompleksno malformacije vretenc(CVM). Metoda PCR-RFLP je bila uporabljena za določanje polimorfizma gena $C D 18$, ki je odgovoren za razvoj dedne bolezni BLAD. Recesivni alel s točkovno mutacijo $A \rightarrow G(383)$, ki povzroča bolezen $B L A D$, je bil ugotovljen v populaciji litvanskega goveda s frekvenco pojavljanja 0,0025. Bolezen CVM je povzročena z drugačno-pomensko mutacijo v genu SLC35A3. Prisotnost mutacije v tem genu smo izvedli z metodo sekvenciranja. Recesivni alel s točkovno mutacijo $G \rightarrow T$ (538), ki povzroča CVM, je bil ugotovljen v populaciji litvanskega goveda s frekvenco pojavljanja 0,005. Testna metoda PCR-RFLP je bila uporabljena za določanje polimorfizma gena UMPS, ki je odgovoren za razvoj dedne bolezni DUMPS. Recesivni alel s točkovno mutacijo C $\rightarrow$ T (1213), ki povzroča DUMPS, ni bil najden v litvanski populaciji holštajnskega goveda. Ker so se v preteklem desetletju izvajali intenzivni selekcijski programi, se je število prenašalcev dednih smrtnih bolezni znatno zmanjšalo.

Ključne besede: govedo; moteno prilepljanje govejih levkocitov; pomanjkanje encima uridin monofosfat sintaze; kompleksna malformacije vretenc; BLAD; DUMPS; CVM 